\title{
Discrete/Continuous: Music and Media Theory after Kittler
}

\section{Citation}

Alexander Rehding, Gundula Kreuzer, Peter McMurray, Sybille Krämer, Roger Moseley Journal of the American Musicological Society, Vol. 70 No. 1, Spring 2017; (pp. 221-256)

\section{Permanent link}

http://nrs.harvard.edu/urn-3:HUL.InstRepos:41392851

\section{Terms of Use}

This article was downloaded from Harvard University's DASH repository, and is made available under the terms and conditions applicable to Open Access Policy Articles, as set forth at http:// nrs.harvard.edu/urn-3:HUL.InstRepos:dash.current.terms-of-use\#OAP

\section{Share Your Story}

The Harvard community has made this article openly available.

Please share how this access benefits you. Submit a story.

\section{Accessibility}




\section{Discrete/Continuous: Media Theory After Kittler}

Introduction

\section{ALEXANDER REHDING}

At first blush, the pair discrete/continuous seems to take us far from the concerns of musicology and place us firmly in the realm of statistics, data analysis, and number crunching. Put graphically, "discrete data" translates into dots or interrupted lines, while "continuous data" implies a curve. This would mean counting and measuringhow can these activities be relevant to music?

Our initial association might be with computers, but it is not necessary to invoke that squishy entity called the "digital humanities" here. ${ }^{1}$ We fare better if we think of the discrete/continuous pair in the context of a different and seemingly outmoded approach to music aesthetics. Going back in time, beyond the influential Kantian tradition, we return to Gottfried Wilhelm Leibniz (1646-1716) of almost a century earlier, the great rationalist and mathematician who invented calculus from his Hanover home at the same time as Newton in Cambridge. Leibniz understood music as a sensory quality that is apprehended by the rational faculty. For him "rational" always meant one thing: counting. He famously defined music as "a hidden arithmetic exercise of the soul, which is unaware of its own counting."2 Kant and Schopenhauer toyed with Leibniz's definition

\footnotetext{
${ }^{1}$ For a media archaeology of the digital, see Siegert's magisterial Passage des Digitalen.

${ }^{2}$ Leibniz, letter to Christian Goldbach of April 17, 1712: “Musica est exercitium arithmeticae occultum nescientis se numerare animae" (the translations in this essay are mine unless otherwise indicated). See also Leisinger, Leibniz-Reflexe, 43-58.
} 
in their writings on aesthetics, but both eventually dismissed it (for different reasons). 3 If Leibniz's counting soul seems a strange way to think about music, then it is because we have forgotten it as other aesthetic issues have become more pressing, notably the work concept and the genius composer. Yet there is much to be (re)gained from this Leibnizian universe.

Leibniz uses, first of all, a different lens for understanding music: instead of considering the compositional perspective, in which the musical material is shaped into themes, motives, and voices, he is far more concerned with the principles from which music emerges. In other words, his is an aesthetics of sound rather than of composed music. This perspective is closer to the Greek term "aisthesis," or perception, which is, after all, the meaning that Alexander Baumgarten had in mind when he coined the term "aesthetics" in 1750-a term, and a time, in every sense halfway between Leibniz and Kant.

The return to Leibniz and the arithmetic paradigm, mathesis universalis, at the beginning of the twenty-first century is a well-calculated move. To be sure, numbers have always been around us: a fairly direct line could be drawn from Leibniz via Joseph Fourier (of "Fourier transform" fame, 1768-1830) to electronic music. The reconsideration of this older approach, however, would not make sense without the explicit realization that our own time is progressively dominated by numbers. The digital realm knows only zeros and ones, and out of these a whole universe can be created-in words, images, or sounds.

\footnotetext{
${ }^{3}$ See Kittler, "Musik als Medium."
} 


\section{Poststructuralist Media Theory}

The landscape of media studies is often divided, for better or worse, along broad linguistic groups centered on anglophone, French, and German traditions. 4 The thinkers usually grouped together under the somewhat misleading label "German media theory," whose best-known representative is the late Friedrich Kittler (1943-2011), are central here, since they have invested a great deal of energy in showing that this world of the machine is not exactly new; we have just forgotten its mechanisms over the course of the last few centuries, essentially since the rise of humanism. Humanism has been a bête noire, or at best something of a distraction, for many media theorists-Kittler would habitually sneer at "so-called man." This profound antihumanism was part of a wider program to drive the Hegelian spirit out of the humanities and move them outside the traditional confines of literary hermeneutics. 5 Instead, Kittler pursued what others have called the "materialities of communication," 6 with a rigorous focus on technology. (He is often criticized for his insistence that entertainment technology, including sound media,

\footnotetext{
${ }^{4}$ Notwithstanding powerful critiques, the Canadian school around McLuhan and Innis occupies a central position in the English-speaking world. In France, Derrida, Baudrillard, and Virilio must be mentioned.

${ }^{5}$ Kittler entered the academic stage with an edited collection bearing the pugnacious title Die Austreibung des Geistes aus den Geisteswissenschaften (1980), a pun that can hardly be translated into English but that promises to exorcise the (Hegelian) spirit/ghost from the humanities ("sciences of the spirit"). Using the same take-no-prisoners approach, he was part of the first generation of German scholars to promote ideas by French poststructuralists, above all Foucault, Derrida, and Lacan, in sharp opposition to the hermeneutic tradition stemming from Gadamer, Dilthey, and Schleiermacher that was prevalent in German literary study.

${ }^{6}$ Gumbrecht and Pfeiffer, Materialities of Communication.
} 
is nothing but a waste product of the military industry. He considered warfare to be the main force of technological innovation.) For Kittler, the only things that have actual existence are data streams. A technophile who never met a hyperbole he did not like, he put it more strongly: "Only that which is switchable exists."7 Kittler's creed is an ontology of circuitry.

The basic principles on which Kittler's media theory builds could not be simpler: data goes in, gets processed, and comes out. Or, in slightly more technical language, a medium is defined by three criteria: selection, storage, transmission. This model is enormously flexible, and it allowed Kittler to consider such disparate things as typewriters, the medieval university, and the city. But sound media have played, perhaps surprisingly, a privileged role in this model. Many musicologists will be familiar with Kittler's work on the gramophone, which fueled a preexisting interest in recording media in musicology. ${ }^{8}$ Kittler argues that conventional musical notation systems, which store, process, and reproduce the notes of the chromatic scale, effectively act as a filter that prevents noise, wrong notes, extraneous sounds-in a word, nonsense-from entering into circulation. The gramophone, by contrast, has no such filter mechanism. It records the sound wave, warts and all. Neither quality nor intended meaning makes a difference to the recording. Sound is recorded qua sound.

The gramophone, in short, is a very different Aufschreibesystem from diastematic notation. "Aufschreibesystem" is usually rendered as "discourse network" but it translates more concretely as "writing-down systems." Kittler's late work, less well

\footnotetext{
${ }^{7}$ Kittler, Draculas Vermächtnis, 182: “Nur was schaltbar ist, ist überhaupt."

${ }^{8}$ Kittler, Gramophone, Film, Typewriter. Some implications for musicological discourse are explored in Rehding, "Wax Cylinder Revolutions."
} 
known in English-speaking countries, takes an even broader notion of Aufschreibesysteme-going all the way back to the vowel alphabet in ancient Greek. ${ }^{9}$ The Greeks adopted the Phoenician alphabet, but tweaked it to suit their needs, most importantly adding vowels. Whereas the Phoenician 'alep signifies a glottal stop, the Greek alpha, for the first time in history, allowed us to write down the vowel "a." This made Greek the first language that anyone could read out aloud, even without understanding its meaning. In Greek it became possible to write down place names such as Circe's island Aiaia, which would elicit only blank stares if we tried to mark it on a map using older, vowelless alphabets. What is more, the Greeks used their letters to write down words, as well as numbers and music. Alpha to theta represented 1-9, iota to koppa the decimals $10-90$, and finally rho to sampi the hundreds..$^{10}$ As for music, certainly vocal music, letters could simply be written above the syllables of a poem, to indicate the pitches at which it should be sung. In the Greek Aufschreibesystem it was possible, at least in principle, to sing numbers, to count up names, or to pronounce melodies.

The vowel alphabet has itself been likened to a gramophone, storing and reproducing sounds. ${ }^{11}$ When viewed in this way the data streams of the ancient Greeks look much like those of the modern digital world, in which the same innocuous mix of

${ }^{9}$ Kittler began a ten-volume series, Musik und Mathematik, which was to extend from ancient Greece to the Turing Galaxy, only the first three volumes of which were published.

${ }^{10}$ Numbers are based on the archaic alphabet, which included a few letters that later fell out of use.

${ }^{11}$ See Ernst and Kittler, Die Geburt des Vokalalphabets. 
zeros and ones can be made to serve any sensory domain-whether image, sound, or words. To the indifferent computer these are nothing but data streams.

\section{After Kittler}

When Kittler died-or rather, transfigured-in 2011, it was with a characteristically theatrical air: "Alle Apparate aus[s]chalten" (Switch off all the machines). ${ }^{12}$ His dying words demonstrated, if any such demonstration were necessary, that he was dead serious about his ontology of switchability. His followers and colleagues took a number of his ideas even further and exploded the notion of media and discourse networks in multiple directions, resulting in what some have likened to a quasi-Hegelian split into "left-Kittlerians" and "right-Kittlerians." ${ }^{13}$ On the one hand, Sybille Krämer's and Bernhard Siegert's explorations of "cultural techniques" expand notions of the kinds of operation that might constitute mediality, which allows the human to reenter the discussion. ${ }^{14}$ One cornerstone of "cultural techniques" is an ontological reversal whereby activities such as counting precede the associated concepts such as number, normally thought to come first. On the other hand, scholars such as Wolfgang Ernst and Jussi Parikka pursue a "media archaeology," writ large, that is to a large extent concerned

\footnotetext{
${ }^{12}$ See Tom McCarthy, "Kittler and the Sirens," London Review of Books Blog, November 9, 2011, accessed February 19, 2016, http: / / www.lrb.co.uk/blog/2011/11/09/tommccarthy / kittler-and-the-sirens/.

${ }^{13}$ See Winthrop-Young, “Cultural Techniques,” 15.

${ }^{14}$ See, for example, Krämer and Bredekamp, Bild-Schrift-Zahl, and Siegert, Cultural Techniques.
} 
with sound and sonic histories. ${ }^{15}$ Always interested in nonlinear narratives, media archaeologies such as Siegfried Zielinski's "variantology" have pushed particularly toward a less canonical and less Eurocentric understanding of where media histories lie. ${ }^{16}$

To put the difference between the two main groups as succinctly as possible, Kittler's media became practices in the hands of the proponents of cultural techniques, whereas the media archaeologists focused on object-centered epistemologies. These media approaches offer enormous possibilities for musicology, broadly conceived, not least as their focus and questions sharpen the view for a perspective that is often thought to be incidental to music. From a media-theoretical perspective, the question of whether sounds are stored in the magnetic charges of a cassette tape, binary code, a music box, or indeed the muscle memory of a pianist is of central significance. Media archaeology argues that the medium is not merely a vehicle that is somehow external to music but is rather inextricably connected with it: the sounds exist only in and by virtue of the medium. And the study of cultural techniques explores seemingly mundane activities-pointing, flattening, grid-making-from the perspective of their medial import. (To take but one example here, the Guidonian hand is the embodiment of a long-standing cultural technique.) ${ }^{17}$ According to either of these approaches, textual, analog, and digital forms of inscription constitute entirely different worlds.

${ }^{15}$ See, for example, Ernst, Digital Memory and Sonic Time Machines; Parikka, What Is Media Archaeology?; and Huhtamo and Parikka, Media Archaeology.

${ }^{16}$ See, for example, Zielinski, Deep Time.

${ }^{17}$ See Wenzel, "Von der Gotteshand." 


\section{Media Archaeology}

The statement "In the beginning was the wheel" is one that media archaeologists could get excited about. Specifically, a "Savart's wheel": take a stiff piece of cardboard, such as a beverage coaster, hold it between the spokes of a bicycle, and turn the wheel. The vibrating coaster will make a sound, its pitch rising as the wheel turns faster. This staple of the scientific demonstration cabinet has a more complicated history than is suggested by its name (which refers to the French physicist Félix Savart, 1791-1841). It was invented over and over again, starting-probably-with Robert Hooke (1635-1703). Its importance is hard to overestimate, its experimental design demonstrating, visually and aurally, the correlation between frequency and pitch. On the basis of the number of teeth on the cog and its rotation speed, we can calculate how many times the cog strikes per second to produce a given pitch. ${ }^{18}$ Clearly excited about his idea, Hooke also told his friend Samuel Pepys that he would be able to identify the buzz of a fly by counting the frequency at which it flapped its wings. ${ }^{19}$

From a musical perspective Hooke's wheel was overshadowed by the invention of the tuning fork only a few decades later. But for a media archaeologist the wheel, which lays bare the underlying mechanics, has great advantages over the tuning fork. It allows us to "reverse-engineer" the mechanism of sound generation. The central question of media archaeology, "How does it work?," erects its epistemology on the material objects it studies. ${ }^{20}$ Naturally, the wheel presents the primal scene of discrete sound generation,

${ }^{18}$ See Inwood, Man Who Knew Too Much, 223-25.

${ }^{19}$ Ibid., 73.

${ }^{20}$ See Parikka, What Is Media Archaeology? 
which returns us to our main focus. Suddenly we are quite close to Leibniz's counting soul.

\section{Cultural Techniques}

"In the beginning was the deed." The hypothesis on yodeling of Carl Stumpf (18481936) makes for a striking example of a cultural technique in the sound world. Stumpf regards music essentially as a technique that serves vocal communication. In trying to convey information across distances, he argues, it is useful for the voice to linger "on a high, fixed pitch at great volume-as produced naturally simply by the greatest tension of the vocal folds." ${ }^{21}$ As the lung volume depletes, the pitch sometimes descends, he further observes, and the sound gains in volume when multiple voices come together. Having deduced music from these calls across mountains, Stumpf extrapolates the emergence of specific musical features that the early twentieth century considered essential to music. Octaves and fifths occur, he explains, if men and women join together in the natural range of their voices. Ringing out strongly, these intervals "fuse" particularly well, which is how he explains the basis of consonance. Motives, he speculates, are easily recognizable signals, which require little data to produce clear signs ideal for calling specific people. From there it is just a small step to melodies, to responsories, and to contrapuntal techniques. ${ }^{22}$

\footnotetext{
${ }^{21}$ Stumpf, Origins of Music, 45.

${ }_{22}$ Ibid., 45-50.
} 
We need not worry about the veracity of Stumpf's whimsical hypothesis here. What matters is the idea that yodeling could be counted as a cultural technique in the sense that fire making, plowing, writing, or counting can be understood: as activities and practices that engender cultural products. ${ }^{23}$ What are the foundations on which culture is erected? The use of technologies in generating knowledge is central here. Writing has doubtless received the greatest attention, but it is hardly the exclusive cultural technique.

In reality there is no hard-and-fast boundary between media archaeology and cultural techniques. It would be possible, in principle, to conduct a media archaeology of yodeling and to examine the cultural technique of spinning Hooke's wheel. The contributions to this colloquy explore various intersections of music and media theory, offering perspectives that resonate with cultural techniques and/or media archaeology. Gundula Kreuzer probes Kittler's deep-seated fascination with Richard Wagner and links it to current concerns in opera studies. Peter McMurray draws on Wolfgang Ernst's idea that a medium can be both object and agent of its own archaeology, but in a move more common in cultural techniques he aims that analysis at the human body, including its potential for disability, and more specifically at the ear. Sybille Krämer returns to the era of mathesis universalis in her exploration of diagrammatics and epistemology in Descartes's work on music from the perspective of cultural techniques. And Roger Moseley scrutinizes Ernst's most recent writings on time-critical media-that is, media that create a sense of temporality. This is a concept with clear repercussions for music, and he finds surprising resonances with historically informed performance.

\footnotetext{
${ }^{23}$ See Krämer, "Cultural Techniques."
} 
Further connecting points between the tenets articulated by media studies and the current interests of musicology are not difficult to find. The various strands within the burgeoning field of sound studies offer the most obvious affinities, but we need not stop there. Nicholas Mathew and Mary Ann Smart's “Quirk Historicism,” "assembling and scrutinizing disparate objects, events, and documents,"24 effortlessly ties in with media archaeology's fascination with forgotten, discarded, or imaginary media objects. And William Cheng's and Benjamin Piekut's adaptations of Bruno Latour's Actor Network Theory (ANT), building on the agency of objects, are commensurable with media theory's "common denominator" that "media not merely transmit data, but alsosomehow-bring them forth." ${ }^{25}$ Many other connections to ongoing musicological work are easily imaginable.

To round off our exploration of Leibnizian aesthetics and its afterlives, let us focus on the year 1843 , a date that does not feature prominently in most conventional music histories but that marks a decisive moment from a media perspective, eclipsing even the invention of the gramophone later the same century. In 1843 Georg Simon Ohm transferred Fourier analysis to the field of acoustics and made musical sounds legible, calculable, and measurable. ${ }^{26}$ It was this turning point that allowed the sound wave to become the bedrock of musical thought. Musicology is only just beginning to evaluate the far-reaching consequences of this watershed, and media theory can help.

${ }^{24}$ Matthew and Smart, "Elephants in the Music Room," 61.

${ }^{25}$ Krämer, “Was haben 'Performativität,'” 23: "der kleinste gemeinsame Nenner"; “dass Medien das, was sie übertragen, zugleich auch - irgendwie - hervorbringen."

${ }^{26}$ Ohm, "Über die Definition des Tones." See particularly Ernst, Sonic Time Machines. 
Whether discrete or continuous, the task is, in Bernhard Siegert's words, to replace the Critique of Reason with a Critique of Media, which is always also a Critique of Culture. ${ }^{27}$

\footnotetext{
${ }^{27}$ Siegert, Cultural Techniques, 1.
} 